Jpn J Human Genet 41, 203-208, 1996

\title{
HIGH-RESOLUTION CHROMOSOME R-BANDING IN LYMPHOBLASTOID CELL LINES BY THE COMBINED USE OF CELL SYNCHRONIZATION AND ETHIDIUM BROMIDE TREATMENT
}

\author{
Mei Hua Ye, Fumiko SaIto-Ohara, and Tatsuro IKeUChI* \\ Department of Cytogenetics, Medical Research Institute, \\ Tokyo Medical and Dental University, 1-5-45 Yushima, \\ Bunkyo-ku, Tokyo 113, Japan
}

\begin{abstract}
Summary A reliable method for obtaining high-resolution R-banded chromosomes from lymphoblastoid cell lines is described. The cell cultures are subjected to S-phase synchronization in the presence of excess thymidine $(300 \mu \mathrm{g} / \mathrm{ml})$ for 17 to $19 \mathrm{hr}$, followed by BrdU treatment (30 $\mu \mathrm{g} / \mathrm{ml})$ for $6.5 \mathrm{hr}$. Prior to harvest, they are exposed to ethidium bromide $(7.5 \mu \mathrm{g} / \mathrm{ml})$ for $1.5 \mathrm{hr}$ and Colcemid $(0.02 \mu \mathrm{g} / \mathrm{ml})$ for $30 \mathrm{~min}$. Using this method, high-resolution R-banded chromosomes at the 550-850 band level were obtained with frequencies as high as $70 \%$ of all mitotic cells. Key Words high-resolution chromosome banding, R-banding, lymphoblastoid cell lines, ethidium bromide, cell synchronization
\end{abstract}

\section{INTRODUCTION}

High-resolution chromosome banding methods using cells at earlier mitotic stages can be divided mainly into two categories. One involves cell synchronization at the S-phase using agents such as methotrexate (MTX), excess thymidine (TdR), or 5-bromodeoxyuridine (BrdU), with subsequent release from the block (cf., Yunis et al., 1978; Rønne, 1992), and the other involves the application of DNA-binding agents, such as ethidium bromide (EB), that inhibit mitotic chromosome condensation ( $c f$., Ikeuchi, 1984). These techniques have been essentially devised for and employed in human peripheral T-lymphocyte cultures with phytohemagglutinin (PHA), and they cannot necessarily be applied to other cell culture systems.

In lymphoblastoid cell lines (LCLs) established by Epstein-Barr virusmediated transformation of peripheral B-lymphocytes, high-resolution banding at more than the 550-band level is fairly difficult, because general experience has

Received July 25, 1995; Revised version accepted December 12, 1995.

* To whom correspondence should be addressed. 
shown that their chromosomes tend to be condensed and shortened at the mitotic stage, compared to those in standard lymphocyte cultures. Kuwano and Kajii (1991) have reported an effective method for LCLs and skin fibroblasts using aphidicolin-induced cell synchronization followed by EB-induced inhibition of chromosome condensation.

We report here another reliable method effectively yielding higher-resolution R-banded chromosomes from LCLs by the combined use of cell synchronization induced by excess TdR (Viegas-Pequignot and Dutrillaux, 1978) and EB treatment (Ikeuchi and Sasaki, 1979).

\section{MATERIALS AND METHODS}

The following three cell lines were used in this study, all of which were obtained from the NIGMS Human Genetic Mutant Cell Depository, Camden, NJ, USA: GM06135 [registered karyotype: 46,XX,t(10;21)(p11.2;q22.3)], GM09528A $[46, X X, t(3 ; 21)(p 24.2 ; q 21)]$, and GM09542 [46,XY,t(10;21)(q24.1;q22.1)]. The cell cultures in suspension were maintained in RPMI 1640 medium supplemented with $10 \%$ fetal calf serum (FCS).

For experiments, the cell cultures in suspension were started at a cell concentration of $2 \times 10^{5} / \mathrm{ml}$, and $24 \mathrm{hr}$ later they were treated with either MTX $\left(1 \times 10^{-7}\right.$ M) or $\operatorname{TdR}\left(1.24 \times 10^{-3} \mathrm{M}, 300 \mu \mathrm{g} / \mathrm{ml}\right)$ for 17 to $19 \mathrm{hr}$. The cells were then released from the S-phase block by centrifugation washing and reincubation in RPMI 1640 medium (10\% FCS) containing BrdU $(30 \mu \mathrm{g} / \mathrm{ml})$. At appropriate time intervals, the cells were harvested for chromosome preparation following short-term treatments with either Colcemid $(0.02 \mu \mathrm{g} / \mathrm{ml}, 30 \mathrm{~min})$ alone or Colcemid $(0.02 \mu \mathrm{g} / \mathrm{ml}$, $30 \mathrm{~min})$ and $\mathrm{EB}(7.5 \mu \mathrm{g} / \mathrm{ml}, 1.5 \mathrm{hr})$ in combination. R-banded chromosomes were prepared as reported previously (Takahashi et al., 1991) with slight modifications: the chromosome slides made using the above procedures were stained with Hoechst $33258(1 \mu \mathrm{g} / \mathrm{ml}, 10 \mathrm{~min})$ and mounted in $2 \times \mathrm{SSC}(\mathrm{pH} 7.4)$ under cover slips. They were then placed on a $75^{\circ} \mathrm{C}$ hot plate for $9 \mathrm{~min}$ while being exposed to UV light at a distance of $1.5 \mathrm{~cm}$ for the last $6 \mathrm{~min}$, and stained with Giemsa.

\section{RESULTS AND DISCUSSION}

Initially, the cells released from the S phase block induced by MTX or TdR treatment were sampled hourly to examine the frequencies of mitotic cells during a period of 4 to $8 \mathrm{hr}$ after BrdU addition. In both the MTX- and TdR-synchronized LCL cultures, the maximum mitotic indices were obtained $6.5 \mathrm{hr}$ after the start of BrdU addition (Fig. 1). It is noteworthy that this timing was considerably delayed in comparison with standard peripheral blood cultures, where the mitotic peak usually occurs 4.5 to $5 \mathrm{hr}$ after release from the S phase block (Yunis $e t$ al., 1978; Drouin et al., 1988). Another finding was that the maximum mitotic indices 


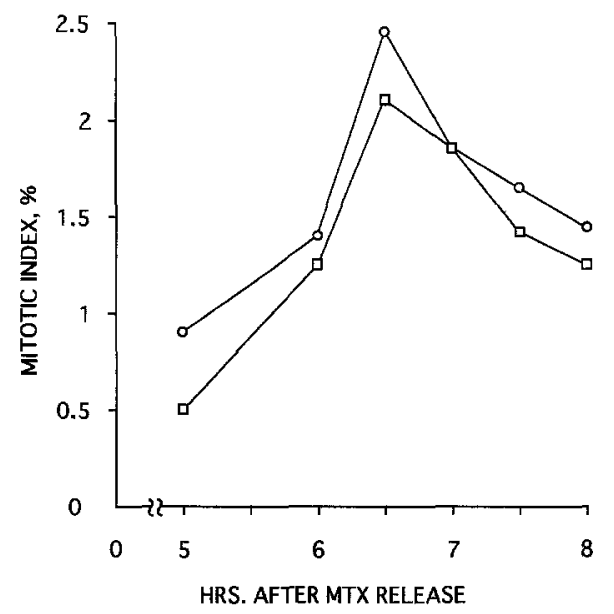

Fig. 1. Sequential changes in mitotic indices after release from MTX-synchronization in the presence of BrdU in cell lines GM09528A (O) and GM09542 ( $\square$ ).

of TdR-synchronized cell cultures were generally higher (3-4\%) than those of MTX-treated cells (2-2.5\%). Similar results have been reported by Drouin et al. (1988), who compared the effects of MTX and TdR as synchronizing agents in peripheral blood lymphocyte cultures with PHA.

In the above preparations obtained from both the MTX- and TdR-synchronized LCLs, the proportions of cells at late prophase to prometaphase among the total mitotic cell population were not high enough for efficient analyses of high-resolution banded chromosomes, even in the samples with the highest mitotic indices. Therefore, application of the EB treatment method (Ikeuchi and Sasaki, 1979; Ikeuchi, 1984) was attempted for the TdR-synchronized cultures at a final concentration of $7.5 \mu \mathrm{g} / \mathrm{ml}$ for $1.5 \mathrm{hr}$ before harvest. Colcemid was added for the last $30 \mathrm{~min}$ of culture. As shown in Fig. 2, a high yield of early mitotic cells showing highly elongated chromosomes was obtained $6.5 \mathrm{hr}$ after BrdU addition: as many as $70 \%$ of mitotic cells were at prophase to prometaphase stages. The late prophase cells available for high-resolution band analysis at more than the 850 -band level accounted for some $10-15 \%$ of the total mitotic cells. In contrast, the frequencies of early mitotic cells in the samples not treated with EB remained at the low level of $20-30 \%$ (Fig. 2). Although the EB treatment results in slight inhibition of mitosis, the mitotic indices of the preparations as seen in Fig. 2 were still around $3 \%$. These figures are considerably better than those achieved by aphidicolin-induced synchronization of LCLs (Kuwano and Kajii, 1991), and are even well comparable with data for peripheral blood lymphocyte cultures subjected to MTX or TdR synchronization (Yunis et al., 1978; Drouin et al., 1988; Rønne, 1992).

The use of $\mathrm{EB}$ in combination with cell synchronization has also been 


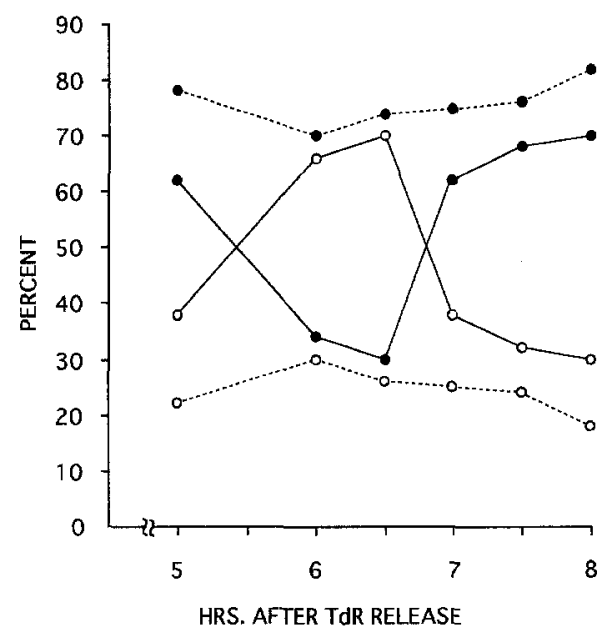

Fig. 2. Sequential changes in proportion of cells at early mitotic stages in the cell line GM06135 after release from excess TdR-synchronization. $O$, prophase to prometaphase; •, metaphase; - Colcemid and EB in combination; ......, Colcemid alone.

successfully applied to cultures of peripheral blood lymphocytes (Rønne, 1985), amniotic fluid cells (Hiramoto et al., 1990) and chorionic villi (Deng et al., 1990), indicating the high availability of EB to a rather wide variety of cell culture systems for high-resolution chromosome banding.

Figure 3 shows some examples of high-resolution R-banded chromosomes (at almost the 850-band level) in the cell line GM09528A, which were obtained by the combined use of $\mathrm{TdR}$ synchronization and EB treatment. Careful sub-band analyses of the reciprocal translocation $\mathrm{t}(3 ; 21)$ revealed the breakpoints to be at 3 p24.3 and 21q21.1, respectively (Fig. 3b). The registered breakpoint on chromosome 3 after GTG band analysis is $3 \mathrm{p} 24.2$. The difference in identification of the breakpoint between the G- and R-banding methods suggests that in reality the breakpoint lies around the border between the $3 \mathrm{p} 24.2$ and $3 \mathrm{p} 24.3$ sub-bands. The breakpoint on chromosome 21 was identified in this study in more detail than the registered one.

Permanently growing LCLs can be routinely established from individuals with chromosome structural abnormalities (Neitzel, 1986; Fukushima et al., 1992), and they have been increasingly employed as important experimental cell sources for molecular genetic analyses, especially for regional mapping and identification of certain genetic disease-related genes and DNA markers (e.g., Arai et al., 1994). The method presented here is readily amenable not only to the refined determination of breakpoints, but also to the direct mapping of DNA probes by fluorescence in situ hybridization on high-resolution R-banded chromosomes from LCLs (Saijo et al., 1994). 

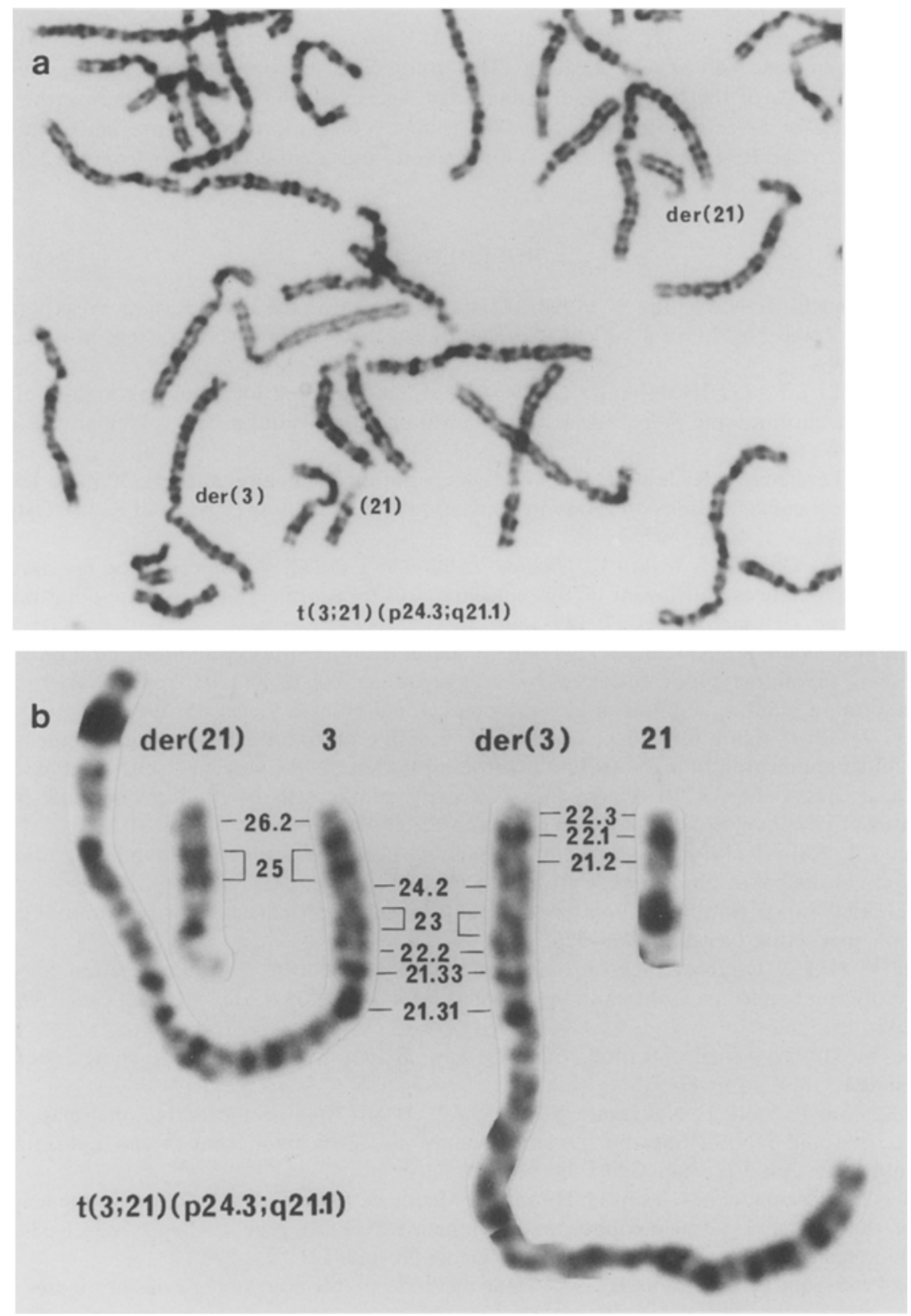

Fig. 3. High-resolution R-banded chromosomes (at almost the 850-band level) obtained by the method presented here from cell line GM09528A. a: A partial spread of a late prophase cell indicating the derivative chromosomes 3 and 21 and normal chromosome 21. b: High-resolution R-banding analysis of the translocation, $\mathrm{t}(3 ; 21)(\mathrm{p} 24.3 ; \mathrm{q} 21.1)$ (see text). 
Acknowledgments We are grateful to Dr. T. Kajii for kind comments and information on aphidicolin-induced cell synchronization. This study was supported in part by Special Coordination Funds of the Science and Technology Agency of the Japanese Government, by a Grant-in-Aid for Scientific Research from the Ministry of Education, Science and Culture of Japan, and by the Research Grant (5A-2) for Nervous and Mental Disorders from the Ministry of Health and Welfare of Japan.

\section{REFERENCES}

Arai E, Ikeuchi T, Nakamura Y (1994): Characterization of the translocation breakpoint on chromosome 22q12.2 in a patient with neurofibromatosis type 2 (NF2). Hum Mol Genet 3: 937-939

Deng HX, Li LY, Xia JH, Niikawa N (1990): A reliable method for obtaining high-resolution banded chromosome preparations from chorionic villus samples. Jpn J Human Genet 35: 189-193

Drouin R, Lemieux N, Richer CL (1988): High-resolution R-banding at the 1250-band level. 1. Technical considerations on cell synchronization and R-banding (RHG and RBG). Cytobios 56, $107-125$

Fukushima Y, Ohashi H, Wakui K, Nishida T, Oh-ishi T (1992): A rapid method for starting a culture for the establishment of Epstein-Barr virus-transformed human lymphoblastoid cell lines. Jpn J Human Genet 37: 149-150

Hiramoto K, Narahara K, Kimoto H (1990): Synchronization culture of amniotic fluid cells using excess thymidine block followed by deoxycytidine release and its application to highresolution banding analysis of chromosomes. Jpn J Human Genet 35: 195-206

Ikeuchi T (1984): Inhibitory effect of ethidium bromide on mitotic chromosome condensation and its application to high-resolution chromosome banding. Cytogenet Cell Genet 38: 56-61

Ikeuchi T, Sasaki M (1979): Accumulation of early mitotic cells in ethidium bromide treated human lymphocyte cultures. Proc Jpn Acad 55: 15-18

Kuwano A, Kajii T (1991): High-resolution banding in chromosomes of B lymphoblastoid cells and cultured skin fibroblasts. Cytogenet Cell Genet 56: 212-213

Neitzel H (1986): A routine method for the establishment of permanent growing lymphoblastoid cell lines. Hum Genet 73: $320-326$

Rønne M (1985): Double synchronization of human lymphocyte cultures: selection for highresolution banded metaphases in the first and second division. Cytogenet Cell Genet 39: 292295

Rønne M (1992): Synchronization, banding and in situ hybridization. A short laboratory manual. In Vivo 6: 49-58

Saijo K, Arai E, Saito F, Nakamura Y, Ikeuchi T (1994): High-resolution regional mapping of 103 plasmid DNA clones on human chromosome 22 by fluorescent in situ hybridization (abstract). Jpn J Human Genet 39: 52

Takahashi E, Yamauchi M, Tsuji H, Hitomi A, Meuth M, Hori T (1991): Chromosome mapping of the human cytidine-5-triphosphate synthetase (CTPS) gene to band $1 \mathrm{p} 34.1-\mathrm{p} 34.3$ by fluorescence in situ hybridization. Hum Genet 88: 119-121

Viegas-Pequignot E, Dutrillaux B (1978): Une mêthode simple pour obtenir des prophases et des promêtaphases. Ann Génét (Paris) 21: 122-125

Yunis JJ, Sawyer JR, Ball DW (1978): The characterization of high-resolution G-banded chromosomes of man. Chromosoma (Berl) 67: 293-307 